\title{
Response to Chouteau and Pedrono: breeding biology of Coquerel's Coua (Coua coquereli) in Western Madagascar
}

\author{
Markus U. Ehrengruber · Urs N. Glutz von Blotzheim
}

Received: 10 July 2009/Revised: 3 May 2011/Accepted: 4 May 2011/Published online: 17 May 2011

(C) Dt. Ornithologen-Gesellschaft e.V. 2011

In their publication entitled "Breeding biology of Coquerel's Coua (Coua coquereli) in Western Madagascar", Chouteau and Pedrono (2009) cite three publications by the Swiss ornithologist and paleontologist Dr. Otto Appert and mention on page 55 that "Appert $(1966,1970,1980)$ provides only anecdotal information about the reproduction of the Coquerel's Coua (Coua coquereli)". Such an assertion should be carefully deliberated. If Chouteau and Pedrono had read Appert's publications in detail they would not have arrived at such a conclusion. Anyone who examines the evidence, such as the annotated colour photographs in Appert (1980), will recognize the inaccuracy of the statement made by Chouteau and Pedrono. Furthermore, the Southern distribution range for C. coquereli given by Chouteau and Pedrono (2009; Fig. 1) is incomplete and partially misleading. A more precise description of the location of $C$. coquereli in this area is provided in Appert (1966, 1970, 1980). Father Otto Appert, as recently summarized (Glutz von Blotzheim 2009), has spent his life in the Mangoky Region, published an extensive body of detailed ornithological work, discovered numerous extinct and existing animal and plant species in Madagascar, including Appert's Tetraka (Xanthomixis apperti; Colston 1972; Cibois et al. 2001) and deserves more respect from scientists working on birds from Madagascar.

\section{References}

Appert O (1966) La répartition géographique des Couas dans la région du Mangoky. Bull Acad Malgache 44:29-36

Appert O (1970) Zur Biologie einiger Kuaarten Madagaskars (Aves, Cuculi). Zool Jahrbuch Syst 97:424-453

Appert O (1980) Erste Farbaufnahmen der Rachenzeichnung junger Kuas von Madagaskar (Cuculi, Couinae). Ornithol Beobachter 77:85-101

Chouteau P, Pedrono M (2009) Breeding biology of Coquerel's Coua (Coua coquereli) in Western Madagascar. J Ornithol 150:55-60

Cibois A, Slikas B, Schulenberg TS, Pasquet E (2001) An endemic radiation of Malagasy songbirds is revealed by mitochondrial DNA sequence data. Evolution 55:1198-1206

Colston PR (1972) A new bulbul from Southwestern Madagascar. Ibis 114:89-92

Glutz von Blotzheim UN (2009) Ornithological research in Switzerland in the course of the $20^{\text {th }}$ century-a fruitful collaboration of professionals and amateurs. Ornithol Beobachter 106:3-48

Communicated by F. Bairlein.

M. U. Ehrengruber $(\bowtie)$

Fachkreis Biologie, Kantonsschule Hohe Promenade,

8090 Zurich, Switzerland

e-mail: markus.ehrengruber@kshp.ch

U. N. Glutz von Blotzheim

"Kappelmatt", Herrengasse 56,

6430 Schwyz, Switzerland

e-mail: ugvb@bluewin.ch 